\title{
Two approaches to the humanities: Claude Lévi-Strauss and Germaine Tillion
}

\author{
Tzvetan Todorov
}

\begin{abstract}
This article compares two different approaches to the humanities in general and to anthropology in particular, represented by two renowned French scholars, Claude Lévi-Strauss (1908-2009) and Germaine Tillion (1907-2008). While LéviStrauss emphasized the importance of an objective stance in the humanities and wanted to eliminate all subjectivity, Tillion desired to reserve an exclusive role for subjectivity, preferring human individuals to abstractions. The article suggests looking for the reason for these opposite positions within the disparate experiences the two scholars had during World War II: an American university life for Lévi-Strauss, and "humanist classes" in a German concentration camp for Tillion. A person who had been through the schooling at Ravensbrück could not arrive at the same conception of the field as another whose experiences came from the campus of an American university.
\end{abstract}

Keywords: anthropology; epistemology; Claude Lévi-Strauss; Germaine Tillion

Germaine Tillion, inducted into the Panthéon in 2015, was the first ethnologist, the first practitioner of the humanities, to receive the honour. While it is true that she was also a member of the Resistance, and that this aspect of her life motivated the President's decision - accompanied as she was by three other resisters - it is no less true that her activity in the Resistance, followed by her imprisonment and deportation to a concentration camp, spanned just five years (1940-1945), while her work as an ethnologist and historian continued over 70 years, from her first foray into the profession in 1932 until the end of her life; and throughout those years she published scholarly studies in which we now recognize her defence of an original conception of the humanities, in certain aspects similar to contemporary research. As for Claude Lévi-Strauss, he played a dominant role both in the history of ethnology in France and in the world; he too thought long and hard about the identity of the humanities, but came to very different conclusions. Of course, Lévi-Strauss' breadth of work, devoted entirely to his field of study, is noticeably larger than that of Germaine Tillion's, who let herself become "distracted" by other engagements; the proximity of their core interests, however, makes it possible to draw a comparison between them using the convention of "parallel lives". 
First among their commonalities is longevity. Tillion was born in 1907, Lévi-Strauss in 1908; they both died 100 years later, in 2008 and 2009, respectively. After studying various subjects in the 1930s, they concurrently discovered the allure and difficulty of the ethnographical landscape. Tillion spent three of the years between 1934 and 1940 in the Algerian Aurès; between 1935 and 1939, Lévi-Strauss taught at the University of São Paulo, and at the same time participated in expeditions carried out in the Amazon and Mato Grosso in Brazil. It was during World War II that the paths of these two apprentice ethnologists would diverge. Their political convictions were not to blame: they were both hostile to Nazi ideology and the German occupation. However, their public engagement took very different forms.

\section{A forbidden paradise}

After a brief conscription in 1939-1940, Lévi-Strauss managed to leave France and find refuge in New York. He taught at the New School for Social Research, where he befriended Roman Jakobson, the Russian linguist who had emigrated to the United States, in what would be a decisive encounter on the intellectual level. Structural linguistics, of which Jakobson was one of the most active proponents, supplied him the theoretical elements that he had hitherto been lacking to complete successfully his work on kinship systems. During his stay, he took part in the founding of the French institution, École libre des hautes études de New York. That did not prevent him from also joining the Free France organisation, founded by de Gaulle, and later the Free French Forces.

At one point, following a proposal made to him by Jacques Soustelle, LéviStrauss was presented with the opportunity to become an ethnologist like him. He had met Soustelle at the Musée de l'Homme in the 1930s; Soustelle had since become Information Commissioner for Free France and, as a representative of de Gaulle, had helped his colleague make his way to America. He visited New York and asked LéviStrauss to follow him to London to take an active part in the fight against the German occupation. Lévi-Strauss declined. "I wanted to study, and the desire to write came to me soon after", he said during his interviews with Didier Eribon (Lévi-Strauss, Eribon 1988: 68). As a consequence, his political activity "frayed". He was satisfied with his participation as a speaker on radio programmes broadcast by The Voice of America. He was profoundly moved by the news of the landings in Normandy, but his priorities lay elsewhere. Having returned to France in the aftermath of the war, he arranged to leave once more for New York, where he would occupy the post of Cultural Counsellor for the French embassy.

As he explained himself, what drew him to the position was by no means a diplomatic career: "I needed American libraries" (Lévi-Strauss, Eribon 1988: 71). It 
was during these years that he began editing his first great work of ethnology that deals with kinship systems.

As for Tillion, she never left the country on whose behalf she swiftly joined the resistance and, more particularly, what she would later call "the network of the Musée de l'Homme". In these novel circumstances, she was constantly discovering previously unknown facets of human nature. Having been deported to Ravensbrück, she observed a society whose norms seemed stranger to her than those which governed the lives of rural Auresians. To protect herself, she conducted something resembling an ethnological survey of the world of the concentration camp.

In the aftermath of the war, the two met once again through their scholarly work. In 1949, Lévi-Strauss published the book Les structures élémentaires de la parenté which propelled him to the highest ranks of French ethnology (and anthropology). In several programmatic appeals he published following this major work - which in 1958 he would compile into one volume whose title, Anthropologie structurale, proclaimed the project's originality - he presented his views on the methodological evolution of the discipline. He began by confirming that "for one or two centuries, social sciences and the humanities resigned themselves to regarding the domain of natural and exact sciences as a paradise to which they would forever be denied access" (Lévi-Strauss 1958: 80; text from 1952). But at the same time, there was a sense of observing the beginning of a new era, of witnessing "the exact moment when anthropology felt closer than ever to becoming a veritable science”, he wrote (Lévi-Strauss 1958: 350-351; text from 1952-1953). According to him, the path of this transformation is demonstrated in exemplary fashion through structural linguistics, embodied in turn by Jakobson. Structural linguistics could boast of the rigour of its analyses, becoming an example to be emulated by the other humanities: "We would like to learn from the linguists about the secret to their success. Couldn't we also..." (Lévi-Strauss 1958: 79; text from 1952). Lévi-Strauss thus suggested that the other disciplines subscribe to a general system of semiotics by studying all social acts as one would a system of signs.

While laying out the "core missions of anthropology", Lévi-Strauss prioritized the objectivity of the scholar. One of the first references to this theme is found in his "Introduction à l'oeuvre de Marcel Mauss". In the context of scientific research, he writes, one must call upon "the capacity of the subject indefinitely to objectify himself, that is (without ever managing to abolish himself as subject) to cast out the everdecreasing fractions of himself" (Lévi-Strauss 1950: xxix). The parenthetical here expresses reserve regarding the possibility of the ethnologist completely neutralizing his subjectivity, but the intention of his work lies within this attempt to "abolish oneself as subject".

That circumspection would wane over the years to follow. "The primary ambition of the anthropologist is to attain objectivity, to instil a taste for it and teach its methods." 
One must do everything to eliminate not just one's value judgements, but also the very concepts supporting those judgements through which one is accustomed to viewing the world. One aspires to find "a valuable formulation, not only for an honest and objective observer, but for all possible observers" (Lévi-Strauss 1958: 398; text from 1954). The fundamental problem of social sciences and the humanities stemmed from the identical nature of the observer and the object of his observation: human beings cut from the same cloth. And since, amongst people, the observer is interested above all in those representations which cannot be observed directly, subjectivity rears its ugly head, on the part of the person being observed as well as on the part of the observer. This preventative work - keeping the observer's subjectivity at arm's length, was part of a larger enterprise promoted by Lévi-Strauss, that of the elimination of the subject, the spoiled child to which Western philosophy had accorded an outsized place. ${ }^{1}$ It was because of the need to struggle "to resolve the problem of objectivity" that Lévi-Strauss was enthusiastic about the situation at the time: "Anthropology is starting to turn towards mathematics and symbolic logic" (Lévi-Strauss 1958: 403).

He goes into further detail in one of the concluding chapters of Tristes Tropiques (written in 1954-1955) entitled, "Un petit verre de rhum" ["A small glass of rum"]. The problem is that this critical objectivity shows up differently, he thought, depending on whether one studies one's own society or another's. When studying one's own society, objectivity on the part of the scholar is impossible since he cannot abstain from bias and judgment. Whereas when studying other societies, objectivity is within reach: the "view from afar", as he would later call it (Lévi-Strauss 1983), is made possible because, by operating within his profession, the ethnologist is "no longer an agent but a spectator," so that he may freely practice "intellectual reflection" such as "aesthetic contemplation". His affiliation with his own society inevitably gives rise to "moral disquiet" within himself, incompatible with the impartiality demanded of him, while objectivity, impossible in the first instance, is "graciously conceded" (LéviStrauss 1984[1955]: 460) to him in the second, in which his mind is free of all moral interference.

The ethnologist conjured up by Lévi-Strauss stands before an unsolvable dilemma, the choice between action and understanding. If he is biased and casts judgment, he forgoes objective understanding; he forgoes science. If he is content to obtain understanding without casting judgment, he forgoes action. "By taking action, one deprives oneself of understanding the rest, but by wanting to understand everything, one resigns oneself to changing nothing" (Lévi-Strauss 1984[1955]: 462). Science is defined here by the objectivity of the understanding; action is always biased: "His role [that of the ethnologist] will only be to understand in whose name one cannot act."

1 I wrote about this in a thirty-year-old study; see Todorov 1986, reprinted in Todorov 1989. 
In one of his last books, Histoire de lynx (1991), Lévi-Strauss (1991: 288) reiterates this concept of incompatibility: the habit of alternating between the two, action and understanding, makes all of us potential schizophrenics: "The wise man preserves his intellectual health through the clear-headed management of this schizophrenia."

In his work on myths, Lévi-Strauss would concede the singularness of the discourse surrounding them, but that singularness itself was unrelated to an increased presence of the knowing subject - and even less so to its inevitability. Instead, he envisaged two modalities of knowledge discourse, both just as objective: logical argumentation and metaphor-infused narrative. Moreover, these two modalities do not just concern the speech of the ethnologist, but also that of the physicist: each time the latter is speaking to non-physicists, to make himself understood he is obliged to resort to narrative and metaphorical imagery. This tactic, however, in no way implies compromised subjectivity. From this perspective, if there is interference between the subjective and the objective, it stems from the internal submission to the ways of the world, not from the influence exerted by the ethnologist-subject on the world he is studying. "The persistence of 'I' [...] must give way to that same object which invades it wholly" (Lévi-Strauss 1971: 559). If there is influence, it is because Lévi-Strauss has become a bit Native American, not because the description of the Native Americans has been influenced by Lévi-Strauss the individual, although this individual in particular was not open to any influence: he described himself as "someone who has never been visited by the slightest religious disquiet” (Lévi-Strauss 1971: 615).

Tristes tropiques is Lévi-Strauss' most personal book and does not touch upon the scientific aspect of its author's oeuvre; it was written during a period of terrible bitterness towards the academic institution, directly following the rejection of his candidacy to the Collège de France. Still, it cannot be said that the author reveals his subjectivity in it. As he states at the end of his work: "The $I$ is not just abhorrent: it has no place between the we and the nothing" (Lévi-Strauss 1984[1955]: 496). We are warned right on the opening page: he refuses to get lost in the memory of his own, worthless experience. He intends to share the results of his observational voyages; the centre of attention will remain the object to be understood, not the subject who understands; and with that in mind, it is not just the individuals, the intermediaries and the informants who interest him. "Adventure has no place in the profession of ethnography, it is simply an obstacle to it." Efforts made "to affect the object of our studies", that is, indigenous society, must be viewed "as the negative side of our profession", he writes (Lévi-Strauss 1984[1955]: 9). All this appears as if Lévi-Strauss had turned a personal choice into a methodological rule, excluding subjectivity as either an object of study or his method of acquiring knowledge. It is tempting to compare this attitude to the admiration he expressed at the time for Roman Jakobson, whose communicative and direct style corresponded to a very different ideal. 
It follows that the best way to eliminate the scholar's subjectivity, according to his work, is to resort to a mathematical language. Linguistics was able to trigger this shift by adopting the then-new theory of information and cybernetics advocated by Norbert Wiener. The ideal of social sciences and the humanities would also consist of their progressive mathematization. The advantage of language, the object of the linguist's study, is that it is "able to satisfy the demands of the mathematician" (Lévi-Strauss 1958: 65; text from 1952), which is why within it, the conditions of a truly scientific study are "all present" (Lévi-Strauss 1958: 64). The mathematics which Lévi-Strauss had in mind was less concerned with the measuring of quantities - a role reserved for statistics - than qualitative structures; what proved particularly useful was recent developments in fields including "mathematical logic, set theory, group theory and topology" (Lévi-Strauss 1958: 310; text from 1952). The ethnologist caught a glimpse of this possibility from his work on kinship structures, at the time benefitting from the advice of the famous mathematician André Weil. Later, concerning the analysis of myths, he enjoyed seeing that the schemas he had created drew the interest of other mathematicians. Yet even if he happened to use notation borrowed from mathematics (remember the formula summarizing the structure of the myth in Lévi-Strauss 1958: 252; text from 1955), Lévi-Strauss never pretended to be doing the work of a mathematician: these formulas had an illustrative role and were not the demonstrative elements.

To summarize, the humanities needed to become like other sciences, and to do so, they needed to rid themselves of any lingering traces of subjectivity; the best way to achieve this goal was to embrace the mathematical ideal, using the trail already blazed by the worthiest of human sciences, linguistics.

On a few rare occasions, Lévi-Strauss envisaged the humanities not as sciences like the others - and still in their beginning stages - but as a different practice of the human mind. They can bring us, he wrote in 1964, "a certain form of wisdom that allows us to err less often because we understand a little better, but without ever drawing a definite line between what we must do in one respect or another" (LéviStrauss 1973: 346), between description and evaluation. This faintly glimpsed path towards the integration of understanding and action would be barred off some years later. Today, it is only brought up so that it may be discredited: this movement of thought is now described as "the quest for a dubitable wisdom" (Lévi-Strauss 1971: 574). In vain, people have searched the numerous writings of Lévi-Strauss for life lessons, for pages offering a certain human wisdom, but he limited himself to the acquisition of knowledge. Instead, if one wants to praise his work, the terms that come to mind are: fireworks, brio, virtuosity.

This exclusive attachment to knowledge could manifest itself as a certain callousness in the way in which Lévi-Strauss treated his academic adversaries. He was 
not happy merely to refute them: he overwhelmed them with his contempt. When he responded to his critics, his words were trenchant: "To reason as Messirs Revel and Rodinson would be to consign the humanities to obscurity" (Lévi-Strauss 1958: 375). His response to Roger Caillois, in 1955, was even more brutal: "Prelogical and backward, Mr. Caillois has yet to arrive at Aristotle. He ignores the law of the excluded middle [...]. We should not confuse the part with the whole" (Lévi-Strauss 1955: 1204). Twenty years later, while welcoming Lévi-Strauss into the Académie Française, Caillois reminded him of the violence of his words: "You answered me in such a tone, with a garrulity, a vehemence, and displaying polemical conduct so rare amidst the controversies of ideas, that at the time, I was simply dumbstruck" (Caillois 1974: 26).

Even during the era of his academic recognition, Lévi-Strauss did not change his ways, as witnessed in the "Finale" of L'homme nu (1971), largely devoted to the refutation of critiques incited by the preceding volumes of the Mythologiques: critiques in which one can only say that Lévi-Strauss found a disparity worthy of attention. They are treated as "imposture" undeserving of the slightest indulgence (Lévi-Strauss 1971: 563), the objections are "so poor that it would be inconsiderate to name their authors" (Lévi-Strauss 1971: 564) (indeed, Lévi-Strauss did not cite the names of his opponents), their authors' attempts to place themselves in opposition to him are deemed "destitute" (Lévi-Strauss 1971: 565), "thus one sees a total ignorance of the things they imprudently claim to resolve" (Lévi-Strauss 1971: 567), their rebuttals are nothing but "dishonest reproaches" (Lévi-Strauss 1971: 571), "platitudes and clichés" (Lévi-Strauss 1971: 572), the critics are too "incapacitated by their ignorance to recognize these problems" (Lévi-Strauss 1971: 572) due to a "sentimental corruption nourished by peremptory and poorly digested understanding" (Lévi-Strauss 1971: 573). Whether they were philosophers, writers or sociologists, those authors who expressed their misgivings or criticized his theses therefore acted out of ignorance or stupidity: these "others" did not deserve his attention.

\section{The "humanist" classes}

From the moment she began her studies in her chosen field in the mid-1930s, Germaine Tillion thought about how she should conduct her investigations. As a young scholar she was convinced in the necessity of making her work as scientific as possible. "In taking on Africa, I had often imagined the 'Sciences of Man' as a sort of chemistry whose mineral precipitates ethnology should avoid disturbing. Luckily, sympathy sometimes forced me to violate my theories" (Tillion 2000: 129). Tillion thus started out where Lévi-Strauss ended up, but she progressively distanced herself from him. "Very naively, I had decided to react against the approximative character 
of our so-called human sciences. Away with uncertainty and away with relativity," she would later recall. However, her momentum was modest. Convinced of the usefulness of rigorous metrics, she also thought that "even exact statistics miss essential elements" (Tillion 2009: 60). She nevertheless endeavoured to write a thesis consistent with the Zeitgeist, devoted to the "complete" study of a Berber tribe. Upon returning to France, she continued working on it, even after she become engaged in the Resistance; indeed, she managed to lay its framework while she was locked up in a French prison, between August 1942 and October 1943. However, the camp at Ravensbrück, where she was subsequently deported, made pursuing this work impossible, and the nearlyfinished thesis disappeared without a trace. Instead, Tillion resigned herself to a sort of ethnological work, in attempting to describe concentration camp society. Once this knowledge had been acquired, she hastened to share it with the other detainees, her comrades in misfortune. Several of them later went on to remember how much these sober classes on the functioning of the camp helped them to endure its rigours.

When Tillion, tested by the years of Resistance, imprisonment and deportation, returned to France at the end of World War II, she struggled to resume her ethnological work. However, in 1946, the British institution that had financed her first two trips in the field asked her to produce a report on the results of her research: and there was no way that money would be spent in vain. Tillion had a great deal of trouble resuming this work that seemed so unreal when compared to her recent experiences, but she succeeded in the end. Still, a surprise awaited her. "When I wanted to wrap up my investigation, the lines got tangled: on one side, the supposedly scientific vein of observation, and on the other, the passionate and lived experience of beings and situations" (Tillion 2009: 276). And not only were these two realisations both genuine: Tillion discovered that the latter affected the former. Between 1940 and 1946, she did not receive any new information concerning the Chaouis of the Aurès, and yet she realised that she no longer understood them in the same way. It was not them that had changed, but her. Her experience in the concentration camp had transformed her, and because of that she beheld the society she studied with different eyes. I cite here an example of her altered perception, which she herself describes as follows:

Of course, I had instinctively felt the modesty surrounding all of the food rites in those countries where famine is chronic. I had felt them instinctively and had even, quite naturally, adopted them, but I did not really understand them until when, in the frigid dawn, I saw staggering phantoms all turn away with one movement so as to not meet the look of another phantom who - suddenly isolated from the others - nibbled in the shadows, while in the absolute silence, you could hear nothing but the great noise of teeth grating against something, lips sucking on something, saliva moistening something, and a throat contracting and relaxing to swallow something. (Tillion 2009: 49-50) 
Tillion described the work of understanding, perpetually being renewed, as a tug-ofwar between two distinct processes. On the one hand, the acquisition of one's own lived experience: "There is but one experience worth anything to each of us: that which we have felt with our own nerves and in our own bones". And, on the other hand, construction of the other: "From the most banal experience that every human being knows or believes to know - hunger - to the highest of experiences - that of tortuous conflicts in which a personality is either reaffirmed or destroyed - nothing, absolutely nothing is made up". To explain their overlap, Tillion resorts to an analogy: "The entire mechanism of our scholarship is like the written notes of a musical score, and our human experience is the musical scale without which the score would remain lifeless. How many historians, psychologists, ethnologists - specialists in mankind while assembling their files, resemble someone deaf from birth copying the sharps and flats of a sonata?" (Tillion 2009: 48-49).

Tillion concludes: "To discuss the humanities, pure scholarship alone does not suffice, and lived experience, deep and diverse, constitutes the essential substrate for the genuine understanding of our species: [...] lived events are the key to observed events" (Tillion 2009: 276). Knowledge in this area thus involves two halves. In one half, one tries to learn, to gather information; its ideal is exactitude and its field is scholarship. In the other half, one tries to understand by selecting, combining and ranking this information; its ideal is depth. "And what would guide the sorting?" Tillion asks, before answering: "Nothing other than one's own acquired experiences" (Tillion 2009: 48). On the one side, one collects facts; on the other, one looks for meanings and causes. However great his efforts and scholarship may be, an ethnologist, a psychologist or an historian with limited personal experience will never be able to produce anything other than a mediocre work of understanding.

Tillion had thus understood this duality in the humanities in 1947, while she was writing her report for the London Institute. Still, she knew that they were expecting "a report for an international scientific journal" (Tillion 2009: 277). In her text, she tried to set aside all conclusions about the inevitable subjectivity of the ethnologist, but she could not quite manage it. And as a result, the report was never published.

Several years later, she entered a second period of active engagement in the public life of her country during the Algerian War, that began in 1954. As she started to emerge from it, after her appointment as Director of Studies at the École Pratique des Hautes Etudes in 1958 (the year in which de Gaulle returned to power and Lévi-Strauss published his Anthropologie structurale), Tillion returned to that once abandoned theme: the working method of ethnology. In the early 1960s, she began writing a work entitled Apprentissages en sciences humaines that would simultaneously take the form of an autobiography. It consists of two parts: In the first, she recounted her experience in the field in Algeria in the 1930s; in the second, she described her experience with 
the resistance and her deportation. This latter training was no less crucial to her development than the former. "It was during that time, and only then, that I redesigned my "humanist" classes, and that I learned about crime and criminals, about suffering and those who suffer, about cowardice and cowards, about fear, hunger, panic, hate, those things without which we aren't human" (Tillion 2009: 179).

A "human science" which excludes from its field the experiences of its "scholars" risks producing useless results. "I would like to state that "scientific" reports - that is, those based on the observation of others - are artificial and false: in order to understand a population, one must both "live" it and "look" at it. Which is why those who are living must learn to look - and those who are looking must learn to live, as a case may be" (Tillion 2009: 179). Far from attempting to rid herself of moral or religious disquiet, Tillion instead considered it an indispensable tool for understanding others.

And yet, in the first half of the 1960s, Tillion realized that she was swimming against the current. Instead of recognizing the subjective aspect of all work in the humanities, the community at large preferred to research objectivity; they chose to devote their attention to mathematics rather than autobiography. Therefore, Tillion abandoned her theoretical book on the methodology of the humanities and devoted herself to work focused on individual subjects. Still, she utilized her new point of view in the central works she would write in the years to come, whether ethnological - like Le harem et les cousins (1966) and Il était une fois l'ethnographie (2000), or historical like Les ennemis complémentaires: Guerre d'Algérie (1960) and Ravensbrück (1973). The author's presence is in no way hidden: Tillion wanted to explain to us the reasons which led her to adopt one or another position, and she intertwined factual information about the world with accounts from her own experience.

In a chapter of Ravensbrück, whose first edition came out in 1973, ten years after an abandoned project entitled, Engagement et impartialité, she returned to the theme of the interpenetration of subjective and objective elements within the study of knowledge, and one has the sense that before writing it, she re-read Lévi-Strauss' reasoning about the crucial impartiality of the scholar. Tillion first affirms that, far from being a nuisance to be eliminated, "bias" is a fundamental characteristic of all human experience.

Living and acting without bias is inconceivable: life is nothing but options, and the clearer they are, the more they lead us astray. All of us, for all that we are, merely decide between parties; we also decide between people, between actions, between explanations for people and actions; and we are constantly wound up, fibre by fibre, in this immense web of events and sequences of which history is sewn. (Tillion 1973: 224) 
Moreover, the historian can neutralize his bias without renouncing his participation in the experience of another. Tillion (1973: 225) concludes: "Bias' will continue to exist in the realm of interpretation, where it is difficult to root out - but, inversely, the total absence of affective "participation" in an event is a quasi-radical element of incomprehension. Between bias and incomprehension lies a narrow window, but this narrowness is part of the problem with history and even, to put it more concisely, with humans". In this domain, the disappearance of subjectivity is an illusion, as nefarious as the illusion denying subjectivity any relevance to observation; it is better to stay clear-headed about the nature of the work one is engaged in.

This point is essential: Tillion in no way suggested that the autobiography of the researcher should replace the observation of a population, research in the archives, and scholarship. What she was calling for was not the substitution of one thing for another, but rather their internal equilibrium. She herself reworked the majority of her oeuvre years after their initial publication dates because she had consulted other sources later and had gathered new information. For example, she published an initial text about the camp to which she had been deported, entitled " $A$ la recherche de la vérite", in the collective volume Ravensbrück in 1946; essentially a testimony and a transcription of the information collected while she was at the camp. A second, completely overhauled version, supplemented by both personal memories and information found from other authors, appeared under the title Ravensbrück in 1973. Lastly, a third version emerged under the same title, augmented by further readings, in 1988. L'Algérie en 1956, presented to her fellow deportees that same year, became L'Algérie en 1957, once it had been expanded the following year, before transforming into L'Afrique bascule vers lavenir in 1960, in yet another modified version; ultimately, a final version using the latter title appeared in 1999, with a significantly altered text. The book of 1960 , Les ennemis complémentaires is half the size of its 2005 second edition. Il était une fois l'ethnographie did not appear until 2000, but the materials serving as its foundation date back to the 1930s, and they had been re-analysed and reformulated countless times. Le Harem et les cousins, from 1966, received a new preface in 1974. All of these rewrites attest to the care that characterizes Tillion's work: the attention to providing the most complete and reliable information possible. Yet this care and attention is accompanied by reminders about the lived experience of the works' author, which give the reader a key to their interpretation.

One finds the same complementarity between the testimony of an event's participants - which seems to be coloured by the subjectivity of the one experiencing the event - and the work of the historian, who consolidates all the available information and tries to neutralize his own subjectivity. In the introduction to her abandoned work on the development of the humanities, Tillion (2009: 44) wrote: "As with all dramas of this world, understanding the Algerian drama required a fusion, the great white 
light of historical enquiry, which brings out every contrast and colour with the arcane incandescence of experience that passes through the thickness of matter. Not simple reason alone, not simple passion alone, but the two of them together, uniting their insufficient glows". Tillion's practice does not call for the selection of one side to the exclusion of the other, subjectivity to the detriment of objectivity or vice versa, but rather the essential interplay of the two.

\section{The campus and the camps}

How did these two ethnologists, whose starting points were so similar, end up so far apart a quarter of a century later? If we follow Tillion's instincts, we must look for the reason for this estrangement within the disparate experiences they had during World War II: an American university life for one of them, and "humanist classes" in a German concentration camp for the other. The two scholars returned armed with equally contrasting convictions; for one, the elimination of all subjectivity, and for the other, the desire to reserve an exclusive role for subjectivity. Their careers during those years thus confirmed Tillion's hypothesis: in the humanities, results of research depend inextricably upon the past experiences of the knowing subject. One who had been through the schooling at Ravensbrück could not arrive at the same conception of the field as one who had been educated on the campus of an American university.

And their conceptions about the role of ethnology are irreconcilable. When years later, a journalist asked Lévi-Strauss what ethnology was good for, he replied: "I can't say it is good for anything, but that is not what I ask of it, nor why it pleases me" (Lévi-Strauss, Eribon 1988: 99). A couple of years earlier, Tillion, inspired by the use she had made of her ethnological enquiry at Ravensbrück, wrote about her return to Algeria in 1954 (where she herself crossed paths with Jacques Soustelle, then a Governor General): "For my part, I would consider the obligations of my profession to be comparable to those of a lawyer, the difference being that I am compelled to defend a whole population instead of an individual. Therefore, it never occurred to me that I could refuse the proposition that was made to me, and, softened by civic-mindedness, I re-packed my suitcase" (Tillion 2007: 430). Even the style of studies each of the two ethnologists produced illustrates this contrast: Lévi-Strauss addressed (except in Tristes tropiques) his university colleagues, while Tillion adopted a much more literary style; she wrote for the lay reader.

Tillion's public involvement leaned on principles connected to those she applied to the domain of the humanities. Her first steps in the resistance movement show us that she was already careful not to identify individuals using transitory categories. The first pamphlet that she published in the underground press called for her comrades 
to combat the occupiers tirelessly, but it also added another demand, "to defy our own hatred" (Tillion 2007: 80). If we do not reduce the person (or the enemy) to his function, we can combat them without hating them. Tillion encountered the same discrepancy after being imprisoned. She discovered to her surprise that being pulled away from active daily combat also had a positive effect: she no longer fell prey to hating the occupiers. At the same time, the prisoners were surrounded by German overseers who had not lost their other human characteristics; empathy or even sympathy towards the resisters was not impossible for them. Returning to Germany after the end of the war to attend the legal proceedings of the Ravensbrück guards, a group of humans much more depraved and aggressive than the overseers at Fresnes, Tillion was pained to discover that the total condemnation with which she viewed their acts did not prevent her from feeling a certain pity for the people, now that it was their turn to be imprisoned and frightened. She realised that, like Christians say, one can condemn the sin, but pardon the sinner, or in layman's terms, "distinguish the crime and the criminal" (Tillion 2007: 51), acting with ruthlessness towards the former and with clemency towards the latter. She went as far as to return to Germany to act as a defence witness at another hearing for Ravensbrück guards: those overseers had been accused of crimes they had not committed.

Tillion's choice asserted itself even more strongly over the course of her second big incursion into public life, during the Algerian War. Whereas from the very start of World War II she had evinced no hesitation in getting involved on the side of the French resistance, in 1954, she found herself facing a paralyzing dilemma: she was torn between her patriotic attachment to her country and the deep sympathy she felt for the Algerian people from when she had worked with them. She refused to kill one to save the other - but what else could one do? Her response: help the suffering, no matter their side, protect and save lives.

Over the following years - which spanned four decades - Tillion never stopped engaging in the public life of her country, not by signing countless petitions, but by constantly tackling specific issues: conditions for prisoners, modern forms of slavery, the status of women in the Mediterranean world, the denunciation of torture, the fate of the undocumented - becoming an advocate for the human race. The reduction of the individual to one of these all-encompassing categories - nationality, ethnicity, class, race, religion, gender - was a step towards his imperilment. Even there, there is a dual view: that of our multiple affiliations (this person is a woman, Muslim, Chaouia, peasant), and that of the individual being. Those whom we do not recognize as beings just as unique and complete as we are risk falling victim to future purges, being pressed into slavery, being relegated to the role of an enemy to be eliminated. 
The scientific method of Germaine Tillion thus corresponds to the principles of her ethics: she refused to neglect human individuals, preferring them to abstractions. However, this choice was not in line with the prevalent thought of the 1960s, neither in the humanities nor in politics. On the one hand, these preferred to defend "the homeland of socialism", the glorious Soviet Union: rather than trying to get the Soviets to open the doors of their (still operating) camps, they extolled political engagement supporting a doctrine (Sartre). On the other hand, they cast their attention towards structures, not human beings, whether the observer or the observed (Lévi-Strauss). In those years, the two projects seemed antithetical: those disappointed with communism taking refuge in what they judged to be the neutral ideology of structuralism. In reality, these antagonistic positions possess a common foundation: in pursuing their ideal (science, social progress), their partisans lost sight of human conscience and experience.

\section{References}

Caillois, Roger 1974. Réponse de M. Roger Caillois au discours de M. Claude Lévi-Strauss. In: Discours prononcés dans la séance publique tenue par l'Académie française pour la réception de M. Claude Lévi-Strauss, le jeudi 27 juin 1974. Paris: Institut de France, 19-38.

Lévi-Strauss, Claude 1950. Introduction à l’œuvre de Marcel Mauss. In: Mauss, Marcel, Sociologie et anthropologie. Paris: Presses Universitaires de France, ix-lii.

- 1955. Diogène couché. Les Temps modernes 110: 1186-1220.

- 1958. Anthropologie structurale. Paris: Plon.

- 1971. Mythologiques, IV: L’Homme nu. Paris: Plon.

- 1973. Anthropologie structurale deux. Paris: Plon.

- 1983. Le regard éloigné. Paris: Plon.

- 1984[1955]. Tristes Tropiques, Paris: Pocket.

- 1991. Histoire de lynx. Paris: Plon.

Lévi-Strauss, Claude; Eribon, Didier 1988. De près et de loin. Paris: Odile Jacob.

Tillion, Germaine 1960. Les ennemis complémentaires: Guerre d'Algérie. Paris: Minuit.

- 1966. Le harem et les cousins. Paris: Seuil.

- 1973. Ravensbrück. Paris: Seuil.

- 2000. Il était une fois l'ethnographie. Paris: Seuil.

- 2007. Combats de guerre et de paix. Paris: Seuil.

- 2009. Fragments de vie. (Todorov, Tzvetan, ed.) Paris: Seuil.

Todorov, Tzvetan 1986. Lévi-Strauss entre universalisme et relativisme. Le Débat 42: 173-192.

- 1989. Nous et les autres: La réflexion française sur la diversité humaine. Paris: Seuil. 


\section{Два подхода к гуманитарным наукам - Клод Леви-Стросс и Жермена Тильон}

В этой статье сравниваются два разных подхода к гуманитарным наукам вообще и к антропологии в частности, представленные двумя знаменитыми французскими учеными Клод Леви-Строссом (1908-2009) и Жерменой Тильон (1907-2008). В то время как ЛевиСтросс подчеркивал важность объективной позиции в гуманитарных науках и хотел устранить всякую субъективность, Тильон хотела зарезервировать исключительную роль для субъективности, предпочитая людей абстракциям. В статье предлагается найти причину этих противоположных позиций в несопоставимом опыте двух ученых во время Второй мировой войны: жизнь американского университета у Леви-Стросса и «уроки гуманизма», усвоенные Тильон в немецком концентрационном лагере. Человек, прошедший школу жизни в Равенсбрюке, не мог прийти к той же концепции, что и другой, живший в кампусе американского университета.

\section{Kaks lähenemist humanitaarteadustele: Claude Lévi-Strauss and Germaine Tillion}

Artiklis kõrvutatakse kahte erinevat lähenemist humanitaarteadustele üldisemalt ning antropoloogiale konkreetsemalt, mida esindasid kaks tunnustatud prantsuse teadlast, Claude Lévi-Strauss (1908-2009) ja Germaine Tillion (1907-2008). Kui Lévi-Strauss rõhutas objektiivse hoiaku olulisust humanitaarias ning tahtis vabaneda igasugusest subjektiivsusest, siis Tillion soovis reserveerida subjektiivsusele eksklusiivset rolli, eelistades inimesi abstraktsioonidele. Artiklis pannakse ette otsida nende vastandlike seisukohtade põhjusi kahe õpetlase erinevatest kogemustest II maailmasõja ajal: Lévi-Straussi elust Ameerika ülikoolis ning Tillioni Saksa koonduslaagris omandatud "humanismiõppetundidest". Inimene, kes oli teinud läbi Ravensbrücki koolituse, ei saanud hakata valdkonda kontseptualiseerima samamoodi kui teine, kelle kogemus pärines Ameerika ülikoolilinnakust. 